AperTO - Archivio Istituzionale Open Access dell'Università di Torino

\title{
Daughters of Esperanto
}

\section{This is the author's manuscript}

Original Citation:

Availability:

This version is available http://hdl.handle.net/2318/1715703

since 2019-11-15T17:13:55Z

Published version:

DOI:10.1075//plp.35.3.05gob

Terms of use:

Open Access

Anyone can freely access the full text of works made available as "Open Access". Works made available under a Creative Commons license can be used according to the terms and conditions of said license. Use of all other works requires consent of the right holder (author or publisher) if not exempted from copyright protection by the applicable law. 
Alan Libert. Daughters of Esperanto. München: Lincom Europa, 2008. v+166 pp.

The comparison of International Auxiliary Languages (IALs) is a key part of the study of planned languages. In fact, when the grammar of a IAL is conceived by the language planner, the existing projects are taken into consideration, often for contrast: the language planner has to convince the public that the newborn IAL is better than the existing ones. Mostly, the arguments brought in favour of the new IAL are structural -- e.g., it has a simpler and more transparent grammar -- as by that ver moment it is still used by no people at all save the language planner. Needless to say, after the first Universal Congress of the Esperanto movement in 1905, the reference point -- positive and negative -- for the new proposals became Zamenhof's IAL (see at least Large 1985 and Forster 1982). Therefore, there is a whole 'family' of IALs that resemble more or less Esperanto, explicitly claiming to be improved reforms of it, that Bausani first (1974) effectively called 'Esperantidos'.

This book compares 30 Esperantidos under a typological point of view: e.g., body part terms for the lexicon, agreement for morphosyntax, synonymy and ambiguity for semantics are presented, when data are available. In fact, most of the Esperantidos presented are shrouded in history: as in many cases only the language planner used them, it is impossible to perform a statistically significant corpus analysis. Rather, the author turns himself to compare the prescriptive grammars written by the language planners, which often contain specimens and examples of the proposed IAL. A point worth of interest is that these 30 Esperantidos were published in very different moments of history: Ido explicitly challenged Esperanto in 1908, while Ayola was proposed almost century later, in 2002, and still in development.

The criterion of judging a IAL belonging to the family of Esperantidos is not strict: Esperanto should be stated as an explicit source by the language planner, and some key features should be clearly of esperantic origin, even if the IAL can have been influenced by others as well. The aim of the book is not to present these planned languages as a whole, but only in relation to Esperanto. As the author says: "in general I only describe points on which these languages differ from Esperanto" (p. 1). In fact, reforms or modifications of Ido -- from a sociolinguistic point of view the most important Esperantido -- are not taken into consideration.

Analogously, languages planned for non-serious purposes are out of the scope -- e.g., for fiction, personal use, humour. However, it is interesting to note how much variety is generated by the language planners of Esperantidos, at any level: from phonetics to semantics, any possible change seemed to be explored; most of them have not a clear or explicit justification for auxiliary purposes, and the reader cannot avoid to think that many proposals are merely exercices de style à la Queneau, without strong efforts (or, at least, faith) in their spread as auxiliary meanings.

It is shown very clearly throughout the book that some parts of Esperanto grammar are less prone to be modified than others. In particular, the Esperanto alphabet shows some diacritics that are "flag characters" of the language -- as for instance $\{\tilde{\mathrm{n}}\}$ in Spanish -- and so some projects try to solve the problem touching the sound inventory. This proved to be a dangerous movement, as the results are often clumsy, because of the need of complex rules in special cases. Another delicate part of grammar is derivational morphology. Having a large set of suffixes quite often lead to complexity in use: the results so less transparent 
compared to Esperanto, that the reader could ask if the language planner is aware of the destiny happened to Volapük! In other cases, for example the vocabulary relating to time, there is almost no differentiation between Esperantidos (if 'second' is sekundo in Esperanto, in Esperantidos it becomes sekondo, sekund or sequndo) or there is only an "etimological shift" from French to English: 'week' in Esperanto is semajno, in some Esperantidos it becames viko, weko, or vek. The important point is that the semantic field of time remains untouched: only the morph, i.e., the signifier, is different.

In sum, this book is interesting not only for interlinguists but also for people involved in language planning issues, because the most tickle points in IAL grammars pose some difficulties shared by minority languages under promotion, for example when looking for a written standard variety.

\section{References}

Bausani, Alessandro (1974). Le lingue inventate: linguaggi artificiali, linguaggi segreti, linguaggi universali. Roma: Astrolabio.

Large, Andrew (1985). The Artificial Language Movement. Oxford and New York: Blackwell. Forster, Peter G. (1982). The Esperanto Movement. The Hague: Mouton.

Reviewer's address

Research Center "Informatica Interattiva" - CRII

University of Insubria

IT 21100 Varese

Italy

federico.gobbo@uninsubria.it

About the reviewer

Federico Gobbo has obtained a PhD in Computer Science from the University of Insubria, where he did research and teaching since 2004. His interests include constructive linguistics, interlinguistics, language planning, history and philosophy of computing. 